\title{
Analisis Penetapan Harga Sewa Berdasarkan Tingkat Subsidi Tertentu Rusun Grudo Kota Surabaya
}

\author{
Nuriyah Irkham dan Christiono Utomo \\ Jurusan Teknik Sipil, Fakultas Teknik Sipil dan Perencanaan, Institut Teknologi Sepuluh Nopember (ITS) \\ Jl. Arief Rahman Hakim, Surabaya 60111 \\ e-mail: nuri.irkham@gmail.com, christiono@ce.its.ac.id
}

\begin{abstract}
Abstrak-Harga sewa yang ditetapkan pada sebuah rusun, semestinya dapat memenuhi biaya operasional, perawatan dan pemeliharaan serta dapat mengembalikan biaya investasi tetapi, harga sewa rusun Grudo tidak dapat memenuhi biaya-biaya tersebut.

Tujuan penelitian ini adalah mengevaluasi harga sewa yang harus diberlakukan sesuai dengan tingkat subsidi tertentu terhadap pengembalian modal investasi pada rusun Grudo. Metode peramalan biaya yang digunakan adalah metode analisis regresi dan analisis akuntansi untuk meramalkan biaya tetap dan biaya variabel. Setelah didapat persamaan biaya, metode analisis titik impas digunakan untuk menetapkan harga sewa unit yang dapat mencapai kondisi impas antara total pengeluaran dengan total pendapatan yang diterima.

Dari hasil perhitungan pada penelitian ini harga sewa sebesar Rp 580.538,-/ unit/ bulan apabila ada subsidi $100 \%$ biaya investasi. Harga sewa Rp 1.574.945,-/ unit/ bulan dengan subsidi hanya biaya tanah dan harga sewa tanpa subsidi adalah sebesar Rp 1.767.225,-/ unit/ bulan.
\end{abstract}

Kata kunci-analisis titik impas, harga sewa unit, Rusun Grudo

\section{PENDAHULUAN}

$\mathrm{S}$ EIRING dengan bertambahnya jumlah penduduk di Kota Surabaya, kebutuhan tempat tinggal juga meningkat, tetapi di sisi lain ketersediaan lahan sangat terbatas. Alasan tersebut menjadikan dibangunnya rumah susun (Rusun) merupakan alternatif terbaik untuk memecahkan masalah kebutuhan perumahan dan pemukiman di kota Surabaya, selain itu juga dapat menjadi salah salah satu cara untuk mengurangi jumlah pemukiman liar dan kumuh di Kota Surabaya.

Rusun Grudo merupakan salah satu rusun kelas sederhana yang terletak di lokasi yang strategis di tengah Kota Surabaya. Harga sewa yang relatif murah sehingga banyak diminati oleh masyarakat yaitu sekitar Rp.36.000,00 sampai dengan Rp.80.000,00 per bulan per unit. Rusun ini mendapatkan subsidi dari pemerintah karena antara harga sewa yang ditetapkan tidak dapat menutupi biaya operasional, perawatan, pemeliharaan dan pengembalian biaya investasi. Oleh karena itu perlu dilakukan evaluasi harga sewa yang dapat menutupi biaya operasional, perawatan, pemeliharaan dan pengembalian terhadap biaya investasi.

Menurut Kotler, penentuan harga sewa berdasarkan pendekatan biaya ada beberapa macam, yaitu harga Mark-Up, penetapan harga biaya plus, dan penetapan harga berdasarkan Break Even Point atau analisis titik impas. Metode yang dipilih adalah metode analisis titik impas. Metode analisis titik impas yaitu metode dimana perusahaan tersebut tidak mendapatkan keuntungan maupun kerugian. Analisis titik impas ini memiliki kelebihan yaitu dapat memperkirakan hubungan antara volume penjualan, biaya, dan tingkat keuntungan yang diperoleh, memperkirakan jumlah keuntungan yang akan dicapai, menghindari kerugian yang dapat terjadi, serta dapat dengan mudah diaplikasikan. Untuk itu analisis titik impas merupakan pilihan terbaik daripada metode lainnya, dan sangat relevan untuk menetapkan harga.

Pada penelitian ini akan dilakukan penetapan harga sewa agar dapat memenuhi biaya-biaya yang dikeluarkan untuk operasional Rusun Grudo dan dapat mengembalikan biaya investasi Rusun Grudo. Dengan analisis titik impas, akan didapatkan harga sewa yang sesuai. Pada penelitian ini juga akan menghitung besar subsidi Pemerintah untuk Rusun Grudo.

\section{PENELITIAN TERDAHULU}

Penelitian terdahulu diantaranya dilakukan oleh [1] dalam penelitiannya berjudul "Analisis Penetapan Harga Jual Unit Rumah di Perumahan Griya Agung Permata". Penelitian ini bertujuan menetapkan harga jual unit rumah pada Perumahan Griya Agung Permata. Penelitian ini dilakukan dengan menetapkan kurva permintaan, menetapkan kurva biaya dan melakukan analisis titik impas untuk menetapkan harga. Dari hasil tersebut diperoleh harga sewa yang optimal untuk masing-masing tipe unit rumah.

Penelitian oleh [2] yang berjudul "Analisis Penetapan Harga Pokok Penjualan Apartemen Puri Park View Tower E Kebon Jeruk Jakarta Barat". Penelitian ini bertujuan untuk menetapkan harga pokok penjualan unit apartemen yang ditetapkan berdasarkan margin profit yang diinginkan mengikuti persamaan harga masing-masing tipe unit apartemen. Hasil analisis harga jual didapat dari analisis biya tetap dan biaya variable yang kemudian dihitung hasil akhirnya menggunakan metode analisis titik impas.

Penelitian oleh [3] yang berjudul "Analisis Penetapan Harga Jual Unit Rumah pada Proyek Perumahan Griya Suci Permata Baru, Gresik". Penelitian ini bertujuan untuk menentukan harga jual unit rumah di Perumahan Griya Suci Permata Baru, Gresik. Pada penelitian ini kurva pendapatan didapatkan dari kurva permintaan. Berdasarkan metode ini diketahui harga jual diterima oleh pengembang dan konsumen. Hasil analisis penetapan harga jual didapatkan dari metode analisis titik impas dimana analisis ini mempertemukan kurva biaya dan kurva pendapatan untuk mendapatkan harga. 
Penelitian oleh [4] yang berjudul "Penetapan harga sewa pada rumah susun sederhana (Rusunawa) Siwalankerto Surabaya”. Penelitian ini dilakukan dengan mencari peramalan biaya dengan metode analisis regresi dan akuntansi. Setelah ditemukan persamaan biayanya, dilakukan pemilihan persamaan biaya yang tepat untuk peramalan biaya. Untuk melakukan penetapan harga digunakan metode analisis titik impas.

Penelitian penelitian yang dilakukan memiliki beberapa persamaan dengan penelitian yang telah ada yaitu menetapkan harga dengan metode pendekatan biaya dengan analisis titik impas. Sedangkan untuk objek penelitian dan metode analisis regresi dan analisis akuntansi memiliki pesamaan dengan penelitian yang dilakukan oleh [4] Perbedaannya adalah, pada penelitian yang dilakukan oleh pada persamaan biaya pengelolaan dengan memperhitungkan biaya konstruksi dan sebagian biaya konstruksi. Sedangkan pada Penelitian ini, menghitung persamaan biaya pengelolaan dengan memperhitungkan biaya pengelolaan saja, biaya pengelolaan ditambah biaya konstruksi dan biaya pengelolaan ditambah seluruh biaya investasi.

\section{METODOLOGI}

Latar belakang :

1. Perbedaan klasifikasi rusun menyebabkan perbedaan tingkat sewa Rusun Grudo Surabaya

2. Harga sewa belum menutupi, biaya operasional, perawatan dan pemeliharaan serta pengembalian terhadap biaya investasi

Identifikasi Masalah :

1. Berapa harga sewa yang harus diberlakukan sesuai dengan tingkat subsidi tertentu terhadap pengembalian modal investasi pada rusun Grudo?

2. Bagaimana kurva harga sewa rusun pada tingkat subsidi tertentu terhadap pengembalian modal investasi?

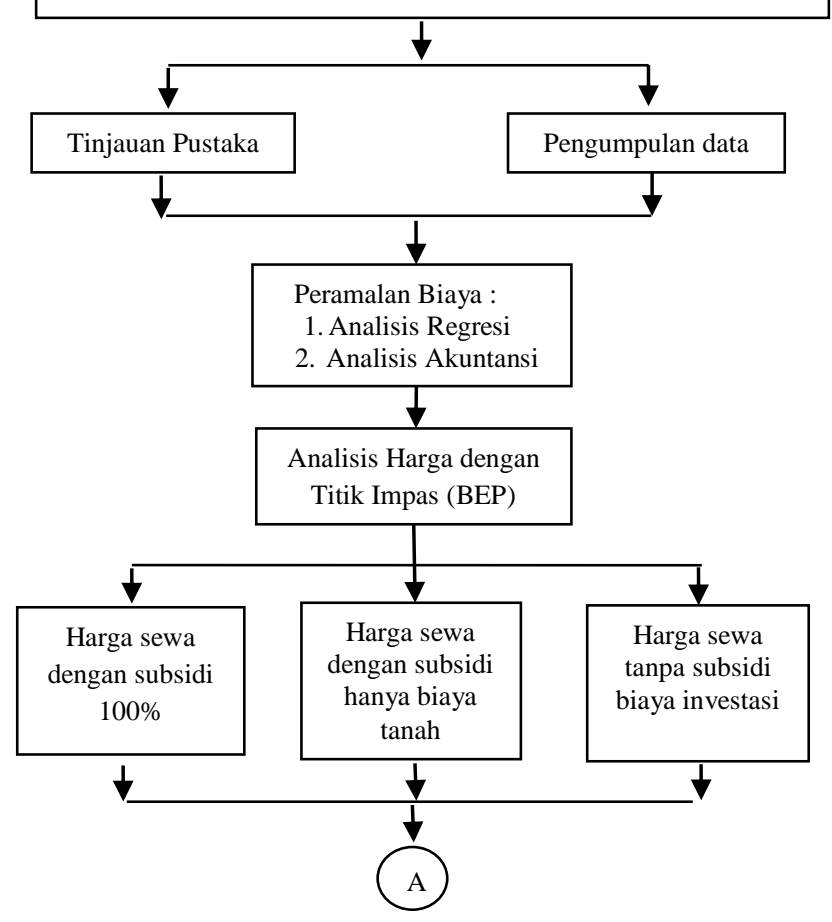

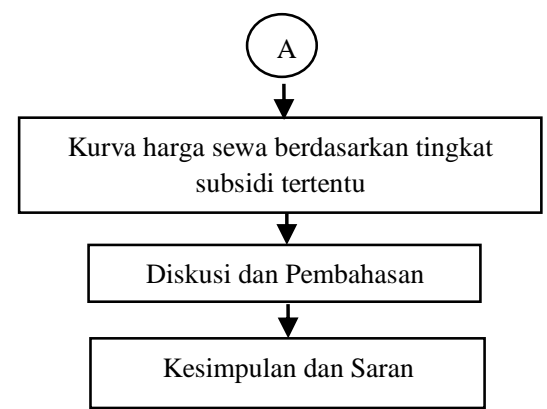

Gambar 1 Diagram Alir Penelitian

\section{ANALISIS DAN PEMBAHASAN}

\section{A. Peramalan Biaya dengan Analisis Regresi}

Analisis regresi yang merupakan salah satu metode statistik ini digunakan untuk mencari pesamanan hubungan antara variabel jumlah unit yang tersewa sebagai variabel bebas (X) dan jumlah biaya total pengolahan rusunawa Grudo sebagai variabel terikat (Y). Dari persamaan tersebut akan didapat perkiraan besarnya biaya tetap dan biaya variabel rusun. Data Biaya Total dan Jumlah Unit Tersewa Oktober 2013 sampai dengan Nopember 2016 dapat dilihat pada Lampiran 1. Hasil dari analisis regresi didapat persamaan yaitu:

\section{$\mathrm{Y}=\mathbf{- R p} 240.200 .000+3.263 .716 \mathrm{X}$}

Biaya Total $=\operatorname{Rp} 240.200 .000+3.263 .716$ unit tersewa $(1)$

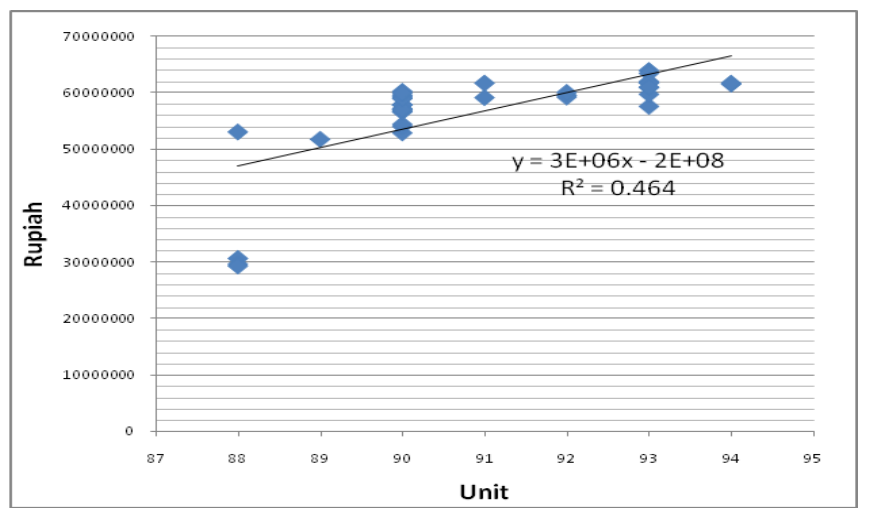

Gambar 2 Diagram Biaya Total dan Unit Tersewa

Dari persamaan tersebut didapat nilai R Square sebesar 0.464 atau unit tersewa hanya mempengaruhi biaya total sebesar $46.4 \%$, sisanya ditentukan oleh variabel lain yang tidak diteliti.

\section{B. Peramalan Biaya dengan Analisis Akuntansi}

Metode analisis akuntansi adalah suatu metode estimasi biaya berdasarkan data biaya lampau yang dikaitkan dengan cost drivernya. Dalam analisis ini beberapa komponenkomponen biaya operasional Rusun Grudo dapat disederhanakan, yaitu komponen biaya tetap meliputi biaya gaji karyawan, biaya pembelian alat kebersihan, biaya pembelian ATK, biaya listrik non penghuni, biaya air non penghuni, biaya perbaikan dan pemeliharaan serta biaya investasi. Sedangkan biaya variabel adalah pembelian papan 
nama penghuni, cetak Brosur, penggandaan formulir pengajuan sewa rusun, formulir perpanjangan sewa rusun, undangan pemanggilan, pemberitahuan perpanjangan sewa, dan kwitansi pembayaran.

Untuk menghitung biaya tetap dalam pengelolaan Rusun Grudo maka jumlah biaya tetap yang terjadi dibagi dengan jumlah bulan pengamatan:

Biaya Tetap = (biaya gaji pegawai + biaya pembelian alat kebersihan + pembelian ATK + biaya listrik non penghuni + biaya air non penghuni + biaya perbaikan dan pemeliharaan) / 38 bulan.

$$
\begin{aligned}
\text { Biaya tetap } & =\frac{R p 2138.328 .456}{38} \\
& =\operatorname{Rp} 56.271 .801,-
\end{aligned}
$$

Perhitungan biaya tetap diatas, belum memperhitungkan biaya investasi. Pengembalian biaya investasi dihitung nilai present value selama 25 tahun, dengan menggunakan tingkat bunga pinjaman Bank Indonesia sebesar 7.20\%.

1. Biaya investasi berupa konstruksi

Biaya Pembangunan $=$ Rp 12.287.867.000

Biaya investasi per bulan:

= Biaya pembangunan

rusun

= Biaya pembangunan rusun

$$
\begin{array}{cc}
\mathrm{X} & (\mathrm{A} / \mathrm{P}, \mathrm{I}, \mathrm{n}) \\
\mathrm{x} & \mathrm{i}(1+\mathrm{i})^{\mathrm{n}} \\
\cline { 2 - 2 } \mathrm{x} & (1+\mathrm{i})^{\mathrm{n}} 1 \\
\mathrm{x} & 0.0720(1+0.0720)^{25} \\
\hline & (1+0.0720)^{25}-1 \\
& 0.0874
\end{array}
$$$$
=\operatorname{Rp} 12.287 .867 .000 \text {,- }
$$

$=\operatorname{Rp} 12.287 .867 .000,-$

$=\operatorname{Rp} 1.073 .959 .575,-$ /tahun

$=\operatorname{Rp} 89.496 .631,-$ /bulan

Biaya tetap total $=\operatorname{Rp} 56.271 .801,-+\operatorname{Rp} 89.496 .631,-$

$$
=\text { Rp 145.768.432,- / bulan,- }
$$

2. Biaya investasi berupa konstruksi dan biaya tanah

Biaya Pembangunan $=$ Rp 12.287.867.000,-

Biaya tanah $=$ Rp 2,376,000,000,-

Biaya investasi per bulan:

$$
\begin{aligned}
& \begin{array}{lll}
=\text { Biaya investasi } & \mathrm{x} & (\mathrm{A} / \mathrm{P}, \mathrm{I}, \mathrm{n})
\end{array} \\
& \text { = Biaya pembangunan }+ \\
& \text { Biaya tanah } \\
& =\operatorname{Rp} 12.287 .867 .000,-+ \\
& \text { Rp2.376.000.000 } \\
& \mathrm{x} \frac{\mathrm{i}(1+\mathrm{i})^{\mathrm{n}}}{(1+\mathrm{i})^{\mathrm{n}}} \\
& \mathrm{x} \\
& \mathrm{x} \frac{0.0720(1+0.0720)^{25}}{(1+0.0720)^{25}-1} \\
& =\operatorname{Rp} 14.663 .867 .000,-\quad \mathrm{X} \\
& 0.0874 \\
& =\operatorname{Rp} 1.281 .621 .976,80 / \text { tahun } \\
& =\operatorname{Rp} 106.801 .831,32-/ \text { bulan }
\end{aligned}
$$

Biaya tetap total $=\operatorname{Rp} 56.271 .801,-+\operatorname{Rp} 106.801 .831,-$

$$
=\operatorname{Rp} 163.073 .632,- \text { / bulan }
$$

Untuk biaya variabel, yang meliputi pembelian papan nama penghuni, cetak Brosur, penggandaan formulir pengajuan sewa rusun, formulir perpanjangan sewa rusun, undangan pemanggilan, pemberitahuan perpanjangan sewa, dan kwitansi pembayaran masing - masing dibagi dengan total unit tersewa.

Dari perhitungan biaya tetap total dan biaya variabel total diatas, diperoleh persamaan biaya rusun Grudo yaitu:

1. Persamaan biaya tetap dengan subsidi biaya investasi

Biaya Total $=\operatorname{Rp} 56.271 .801,-+\operatorname{Rp} 1.807 \times$ unit tersewa (2)
2. Persamaan biaya tetap dengansubsidi biaya tanah

Biaya Total $=$ Rp 145.768.432 + Rp $1.807 \times$ unit tersewa (3)

3. Persamaan biaya tetap tanpa subsidi biaya investasi

Biaya Total $=\operatorname{Rp} 163.073 .632+\operatorname{Rp} 1.807 \times$ unit tersewa (4)

Tabel 1

Perhitungan Biaya Variabel

\begin{tabular}{lrrr}
\hline \multicolumn{1}{c}{ Keterangan } & Biaya (a) & $\begin{array}{c}\text { Total Unit } \\
\text { Tersewa (b) }\end{array}$ & $\begin{array}{c}\text { Biaya } \\
\text { Variabel }\end{array}$ \\
\hline Papan Nama (Rp) & $2,350,000$ & 3,454 & 680 \\
Brosur (Rp) & 163,200 & 3,454 & 47 \\
Form Pendaftaran (Rp) & 94,000 & 3,454 & 27 \\
Formulir Perpanjangan (Rp) & 20,000 & 3,454 & 6 \\
Undangan (Rp) & 94,000 & 3,454 & 27 \\
& & & 19 \\
Pemberitahuan & & & 1.000 \\
Perpanjangan (Rp) & 66,000 & 3,454 & 1.807 \\
Kwitansi Pembayaran (Rp) & $3,454,000$ & 3,454 & \\
Biaya Variabel & & & \\
\hline
\end{tabular}

\section{Pemilihan Persamaan Biaya}

Setelah mendapatkan persamaan dari analisis regreasi dan analisis akuntansi, selanjutnya menentukan persamaan yang paling tepat untuk digunakan pada tahap perhitungan selanjutnya. Pedoman dalam memilih persamaan menurut Hilton (2003) yaitu:

1. Economic plausibility. Artinya persamaan tersebut harus mendekati kebenaran secara ekonomi atau masuk akal. Ini kriteria penting karena persamaan biaya haris masuk akal.

2. Goodness of fit. Dalam analisis regresi, ukuran $\mathrm{R}^{2}(\mathrm{R}-$ square dapat dijadikan patokan untuk menentukan persamaan yang tepat, semakin besar $\mathrm{R}^{2}$ (semakin mendekati nilai 1) semakin tepat persamaan tersebut untuk digunakan.

3. Signifikansi variabel bebas. Yaitu variabel bebasnya signifikan atau tidak. Hal ini dapat diketahui dengan cara uji hipotesa atau uji t. (Hilton, 2003)

Pedoman-perdoman tersebut akan digunakan menentukan persamaan yang dapat dipakai untuk tahap perhitungan harga sewa rusun Grudo selanjutnya.

Persamaan 4.1 adalah persamaan regresi setelah ditambah dengan biaya investasi sebesar Rp 89.496.631,- yang dikeluarkan untuk pembangunan fisik rusun persamaannya adalah:

Biaya Total $=\operatorname{Rp} 329.496 .631+3.263 .716 \times$ unit tersewa

Apabila ditinjau dari nilai $\mathrm{R}^{2}$ persamaan, maka dapat dikatakan bahwa persamaan tersebut sesuai dengan pedoman penentuan persamaan yang kedua, yaitu goodness of fit karena nilai $\mathrm{R}^{2}$ besarnya mencapai 0.464 . Persamaan ini memiliki nilai yang kecil yang berarti biaya total hanya dipengaruhi oleh luas tersewa sebesar $46.4 \%$ sehingga biaya total lebih besar dipengaruhi factor lain yang tidak diteliti. Sehingga kriteria kedua yaitu goodness of fit tidak memenuhi persamaan ini. Untuk melihat pengaruh signifikan biaya unit tersewa sebesar 3.263.716 terhadap biaya total, maka diuji dengan $\mathrm{t}$ dimana t dengan hipotesis.

Uji hipotesanya adalah : 
$\mathrm{H}_{0}$ : koefisien biaya unit tersewa berpengaruh terhadap biaya total

$\mathrm{H}_{1}$ : koefisien biaya unit tersewa tidak berpengaruh terhadap biaya total

Dari hasil perhitungan komputer diperoleh nilai t hitung sebesar 31.212 sedangkan t table sebesar 5.587 secara umum dikatakan apabila nilai t lebih kecil daripada t hitung maka $\mathrm{H} 0$ ditolak yang berarti menerima H1. Jadi dapat dikatakan bahwa hasil regresi ini tidak signifikan. Dengan demikian persamaan Rp 329.496.631 + 3.263.716 x jumlah unit tersewa tidak dapat digunakan untuk meramalkan biaya pada tahap perhitungan selanjutnya.

Selanjutnya untuk persamaan 2 perhitungan dengan metode akuntansi. Terlihat bahwa persamaan tersebut memenuhi kriteria yang pertama, yaitu Economic Plausibility mengingat persamaan tersebut nampak mendekati kebenaran secara ekonomi dan masuk akal. Dan persamaan akuntansi tidak perlu ditinjau lebih jauh karena tidak ada batasanbatasan yang mempengaruhi maka, dapat disimpulkan bahwa persamaan ini dapat digunakan untuk meramalkan biaya pengelolaan Rusun Grudo.

\section{Penetapan Harga}

Setelah didapatkan persamaan yang tepat, maka selanjutnya adalah menentukan harga dengan break even. Metode ini diterapkan melalui grafik titik impas, sehingga dapat ditetapkan harga yang dapat mencapai titik impas tertentu atau membuat tingkat laba yang dicari. Dengan persamaan yang didapat melalui analisis metode akuntansi didapat Perhitungan harga, titik impas, margin kontribusi dan laba dan dapat dilihat pada Lampiran 2. Dengan pendapatan minimum luas unit yang tersewa adalah 90 unit maka, diperoleh :

1. Harga sewa yang diperoleh dengan subsidi biaya investasi 100\% adalah sebesar Rp 627.049.- /bulan /unit dan ketika unit tersewa penuh akan mendapatkan laba sebesar Rp 3.751.452.- sebagaimana gambar 2 .

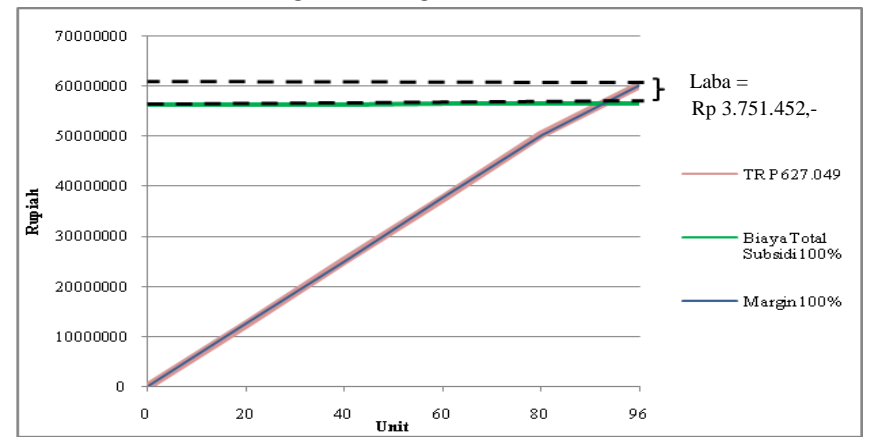

Gambar 2 Grafik Break Even untuk Harga Sewa Rp 627.049/ bulan/ unit

2. Harga sewa yang diperoleh dengan subsidi biaya tanah adalah sebesar Rp 1.621.456.- /bulan /unit dan ketika unit tersewa penuh akan mendapatkan laba sebesar $\mathrm{Rp}$ 9.717.896.- seperti gambar 3

3. Harga sewa yang diperoleh tanpa subsidi biaya investasi adalah sebesar Rp 1.813.736.- dan ketika unit tersewa penuh akan mendapatkan laba sebesar Rp 10.871.575.seperti gambar 4 .

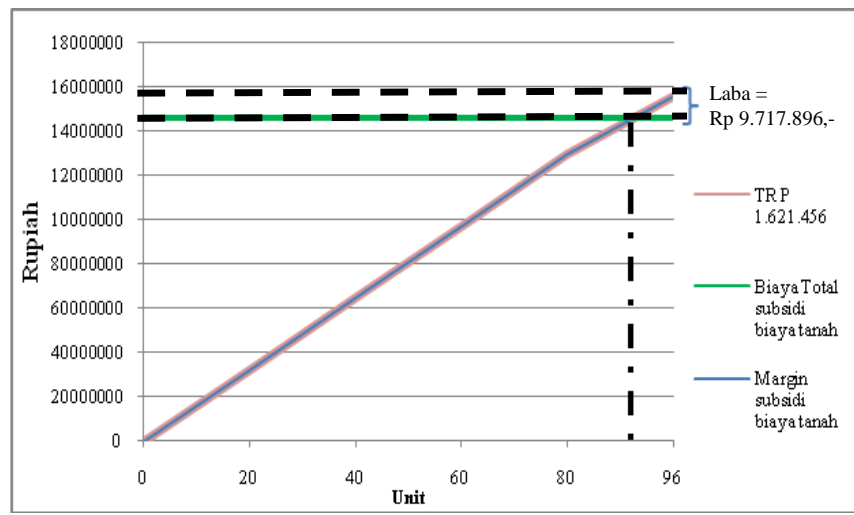

Gambar 3 Grafik Break Even untuk Harga Sewa Rp 1.621.456.-/ bulan/ unit

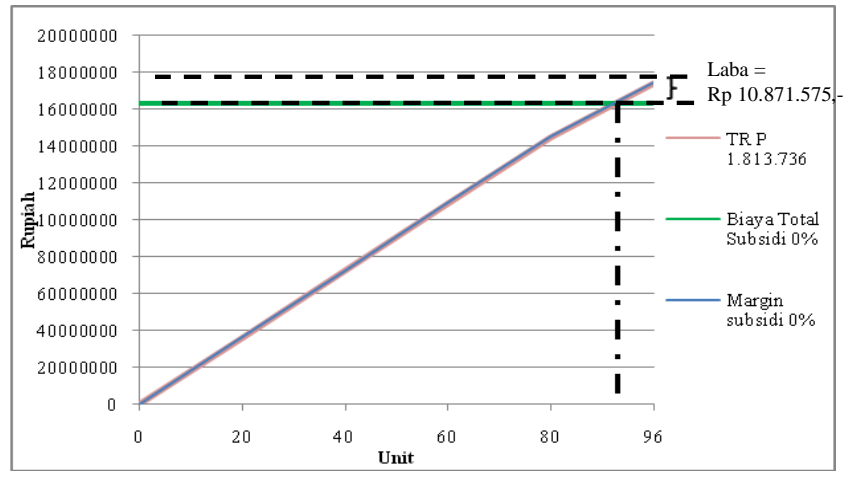

Gambar 4 Grafik Break Even untuk Harga Sewa Rp 1.813.736/ bulan/ unit

Dengan demikian didapat kurva harga sewa Rusun Grudo berdasarkan tingkat subsidi tertentu dan harga sewa eksisting sebagaimana gambar 5

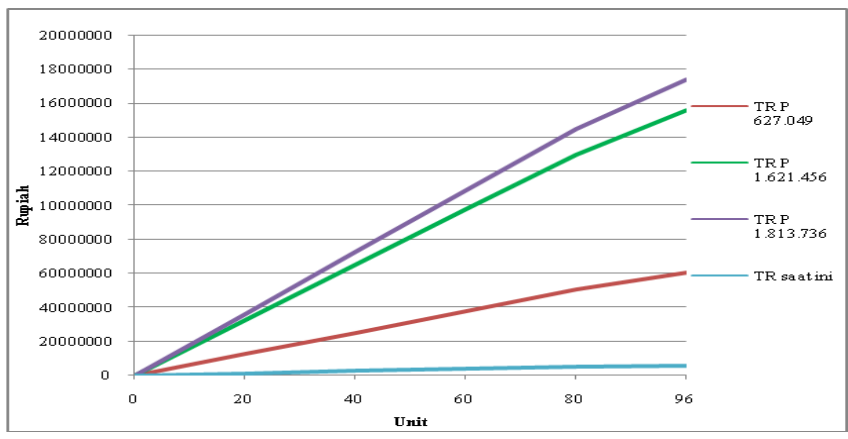

Gambar 5 Grafik Harga Sewa Eksisting, Harga Sewa dengan Subsidi Biaya Investasi, Harga Sewa dengan Subsidi Biaya Tanah, Harga Sewa tanpa Subsidi

\section{KESIMPULAN}

Dari perhitungan dan analisis yang telah dilakukan maka dapat disimpulkan sebagai berikut:

1. Persamaan biaya

a. Persamaan biaya untuk pengelolaan Rusun Grudo tanpa memperhitungkan biaya investasi yaitu

Biaya Total $=\operatorname{Rp} 56.271 .801,-+R p 1.807 \times$ unit tersewa

b. Persamaan biaya untuk pengelolaan Rusun Grudo dengan memperhitungkan biaya investasi berupa biaya konstruksi yaitu 
Biaya Total $=\operatorname{Rp} 145.768 .432+\mathrm{Rp} 1.807 \times$ unit tersewa

c. Persamaan biaya untuk pengelolaan Rusun Grudo dengan memperhitungkan biaya investasi berupa biaya konstruksi dan biaya tanah yaitu

Biaya Total $=\operatorname{Rp} 163.073 .632+\operatorname{Rp} 1.807 \times$ unit tersewa

2. Dari hasil perhitungan penetapan harga maka didapat:

a. a.Harga sewa apabila ada subsidi $100 \%$ biaya investasi adalah sebesar Rp 627.049.- /bulan /unit.

b. b.Harga sewa dengan subsidi hanya biaya tanah adalah sebesar Rp. 1.621.456.- /bulan /unit.

c. c.Harga sewa tanpa subsidi biaya investasi adalah sebesar Rp 1.813.736.- /bulan /unit.

\section{LAMPIRAN}

\begin{tabular}{|c|c|c|c|c|c|c|}
\hline No & Bulan & $\begin{array}{c}\text { Total } \\
\text { BiayaTetap } \\
\text { (Rp) }\end{array}$ & $\begin{array}{c}\text { Total } \\
\text { Biaya } \\
\text { Variabel } \\
(\mathrm{Rp})\end{array}$ & $\begin{array}{l}\text { Total Biaya } \\
\text { (Rp) }\end{array}$ & $\begin{array}{c}\text { Unit } \\
\text { Tersewa }\end{array}$ & $\begin{array}{c}\text { Occupacy } \\
\text { Rate }\end{array}$ \\
\hline 1 & Oct-13 & $27,984,816$ & $2,627,200$ & $30,612,016$ & 88 & $91.67 \%$ \\
\hline 2 & Nov-13 & $29,511,195$ & 88,000 & $29,599,195$ & 88 & $91.67 \%$ \\
\hline 3 & Dec-13 & $29,199,375$ & 88,000 & $29,287,375$ & 88 & $91.67 \%$ \\
\hline 4 & Jan-14 & $52,931,045$ & 88,000 & $53,019,045$ & 88 & $91.67 \%$ \\
\hline 5 & Feb-14 & $52,712,480$ & 144,000 & $52,856,480$ & 90 & $93.75 \%$ \\
\hline 6 & Mar-14 & $51,630,826$ & 89,000 & $51,719,826$ & 89 & $92.71 \%$ \\
\hline 7 & Apr-14 & $53,907,405$ & 90,000 & $53,997,405$ & 90 & $93.75 \%$ \\
\hline 8 & May-14 & $54,277,528$ & 90,000 & $54,367,528$ & 90 & $93.75 \%$ \\
\hline 9 & Jun-14 & $57,077,550$ & 90,000 & $57,167,550$ & 90 & $93.75 \%$ \\
\hline 10 & Jul-14 & $56,803,247$ & 90,000 & $56,893,247$ & 90 & $93.75 \%$ \\
\hline 11 & Aug-14 & $56,558,333$ & 90,000 & $56,648,333$ & 90 & $93.75 \%$ \\
\hline 12 & Sep-14 & $57,735,167$ & 90,000 & $57,825,167$ & 90 & $93.75 \%$ \\
\hline 13 & Oct-14 & $56,488,243$ & 90,000 & $56,578,243$ & 90 & $93.75 \%$ \\
\hline 14 & Nov-14 & $57,735,167$ & 90,000 & $57,825,167$ & 90 & $93.75 \%$ \\
\hline 15 & Dec-14 & $57,735,167$ & 90,000 & $57,825,167$ & 90 & $93.75 \%$ \\
\hline 16 & Jan-15 & $60,132,961$ & 90,000 & $60,222,961$ & 90 & $93.75 \%$ \\
\hline 17 & Feb-15 & $59,446,552$ & 90,000 & $59,536,552$ & 90 & $93.75 \%$ \\
\hline 18 & Mar-15 & $56,903,720$ & 90,000 & $56,993,720$ & 90 & $93.75 \%$ \\
\hline 19 & Apr-15 & $58,933,924$ & 90,000 & $59,023,924$ & 90 & $93.75 \%$ \\
\hline 20 & May-15 & $59,173,465$ & 90,000 & $59,263,465$ & 90 & $93.75 \%$ \\
\hline 21 & Jun-15 & $58,836,751$ & 90,000 & $58,926,751$ & 90 & $93.75 \%$ \\
\hline 22 & Jul-15 & $59,823,720$ & 90,000 & $59,913,720$ & 90 & $93.75 \%$ \\
\hline 23 & Aug-15 & $58,981,360$ & 118,000 & $59,099,360$ & 91 & $94.79 \%$ \\
\hline 24 & Sep-15 & $61,591,885$ & 91,000 & $61,682,885$ & 91 & $94.79 \%$ \\
\hline 25 & Oct-15 & $59,387,824$ & 119,000 & $59,506,824$ & 92 & $95.83 \%$ \\
\hline 26 & Nov-15 & $59,109,014$ & 92,000 & $59,201,014$ & 92 & $95.83 \%$ \\
\hline 27 & Dec-15 & $59,938,633$ & 92,000 & $60,030,633$ & 92 & $95.83 \%$ \\
\hline 28 & Jan-16 & $63,787,388$ & 120,000 & $63,907,388$ & 93 & $96.88 \%$ \\
\hline 29 & Feb-16 & $63,314,210$ & 98,000 & $63,412,210$ & 93 & $96.88 \%$ \\
\hline 30 & Mar-16 & $57,454,764$ & 94,000 & $57,548,764$ & 93 & $96.88 \%$ \\
\hline 31 & Apr-16 & $61,633,148$ & 102,000 & $61,735,148$ & 93 & $96.88 \%$ \\
\hline 32 & May-16 & $60,799,016$ & 98,000 & $60,897,016$ & 93 & $96.88 \%$ \\
\hline 33 & Jun-16 & $61,847,393$ & 93,000 & $61,940,393$ & 93 & $96.88 \%$ \\
\hline 34 & Jul-16 & $61,601,051$ & 93,000 & $61,694,051$ & 93 & $96.88 \%$ \\
\hline 35 & Aug-16 & $59,603,714$ & 93,000 & $59,696,714$ & 93 & $96.88 \%$ \\
\hline 36 & Sep-16 & $60,848,867$ & 93,000 & $60,941,867$ & 93 & $96.88 \%$ \\
\hline 37 & Oct-16 & $61,313,998$ & 187,000 & $61,500,998$ & 94 & $97.92 \%$ \\
\hline 38 & Nov-16 & $61,577,557$ & 94,000 & $61,671,557$ & 94 & $97.92 \%$ \\
\hline \multicolumn{2}{|c|}{ Total } & $2,138,328,456$ & & $2,114,569,656$ & & \\
\hline
\end{tabular}

Lampiran 2 Perhitungan Harga, Titik Impas, Margin Kontribusi dan Laba untuk persamaaan (2)

\begin{tabular}{ccccc}
\hline $\begin{array}{c}\text { Jumlah Unit } \\
\text { yang } \\
\begin{array}{c}\text { diperlukan } \\
\text { untuk Break } \\
\text { Even }\end{array}\end{array}$ & $\begin{array}{c}\text { Harga sewa/ } \\
\text { Bulan/ Unit } \\
(\mathrm{Rp})\end{array}$ & $\begin{array}{c}\text { Margin } \\
\text { Kontribusi } \\
(\mathrm{Rp})\end{array}$ & $\begin{array}{c}\text { Rasio } \\
\text { Margin } \\
\text { Kontribusi }\end{array}$ & $\begin{array}{c}\text { Laba yang } \\
\text { diperoleh } \\
\text { dengan } \\
\text { Maksimum } \\
96 \text { Unit } \\
\text { tersewa }\end{array}$ \\
\hline 96 & & & & - \\
95 & 587,972 & 586,165 & $99.69 \%$ & 592,334 \\
\hline
\end{tabular}

\begin{tabular}{|c|c|c|c|c|}
\hline $\begin{array}{c}\text { Jumlah Unit } \\
\text { yang } \\
\text { diperlukan } \\
\text { untuk Break } \\
\text { Even }\end{array}$ & $\begin{array}{l}\text { Harga sewa/ } \\
\text { Bulan/ Unit } \\
\text { (Rp) }\end{array}$ & $\begin{array}{l}\text { Margin } \\
\text { Kontribusi } \\
\text { (Rp) }\end{array}$ & $\begin{array}{c}\text { Rasio } \\
\text { Margin } \\
\text { Kontribusi }\end{array}$ & $\begin{array}{c}\text { Laba yang } \\
\text { diperoleh } \\
\text { dengan } \\
\text { Maksimum } \\
96 \text { Unit } \\
\text { tersewa }\end{array}$ \\
\hline 94 & 600,443 & 598,636 & $99.70 \%$ & $1,197,271$ \\
\hline 93 & 606,880 & 605,073 & $99.70 \%$ & $1,815,218$ \\
\hline 92 & 613,457 & 611,650 & $99.71 \%$ & $2,446,599$ \\
\hline 91 & 620,178 & 618,371 & $99.71 \%$ & $3,091,856$ \\
\hline 90 & 627,049 & 625,242 & $99.71 \%$ & $3,751,452$ \\
\hline 89 & 634,074 & 632,267 & $99.72 \%$ & $4,425,871$ \\
\hline 88 & 641,259 & 639,452 & $99.72 \%$ & $5,115,617$ \\
\hline 87 & 648,609 & 646,802 & $99.72 \%$ & $5,821,220$ \\
\hline 86 & 656,130 & 654,323 & $99.72 \%$ & $6,543,232$ \\
\hline 85 & 663,828 & 662,021 & $99.73 \%$ & $7,282,232$ \\
\hline 84 & 671,709 & 669,902 & $99.73 \%$ & $8,038,828$ \\
\hline 83 & 679,780 & 677,974 & $99.73 \%$ & $8,813,655$ \\
\hline 82 & 688,048 & 686,241 & $99.74 \%$ & $9,607,380$ \\
\hline 81 & 696,521 & 694,714 & $99.74 \%$ & $10,420,703$ \\
\hline 80 & 705,204 & 703,398 & $99.74 \%$ & $11,254,359$ \\
\hline 79 & 714,108 & 712,301 & $99.75 \%$ & $12,109,121$ \\
\hline 78 & 723,240 & 721,433 & $99.75 \%$ & $12,985,799$ \\
\hline 77 & 732,610 & 730,803 & $99.75 \%$ & $13,885,249$ \\
\hline 76 & 742,225 & 740,418 & $99.76 \%$ & $14,808,368$ \\
\hline 75 & 752,098 & 750,291 & $99.76 \%$ & $15,756,103$ \\
\hline 74 & 762,237 & 760,430 & $99.76 \%$ & $16,729,453$ \\
\hline 73 & 772,654 & 770,847 & $99.77 \%$ & $17,729,471$ \\
\hline 72 & 783,360 & 781,553 & $99.77 \%$ & $18,757,266$ \\
\hline 71 & 794,368 & 792,561 & $99.77 \%$ & $19,814,013$ \\
\hline 70 & 805,690 & 803,883 & $99.78 \%$ & $20,900,954$ \\
\hline 69 & 817,340 & 815,533 & $99.78 \%$ & $22,019,399$ \\
\hline 68 & 829,333 & 827,526 & $99.78 \%$ & $23,170,741$ \\
\hline 67 & 841,685 & 839,878 & $99.79 \%$ & $24,356,450$ \\
\hline 66 & 854,410 & 852,603 & $99.79 \%$ & $25,578,090$ \\
\hline 65 & 867,527 & 865,720 & $99.79 \%$ & $26,837,320$ \\
\hline 60 & 939,670 & 937,863 & $99.81 \%$ & $33,763,080$ \\
\hline 40 & $1,408,602$ & $78,780,521$ & $99.87 \%$ & $78,780,521$ \\
\hline 20 & $2,815,397$ & $213,832,845$ & $99.94 \%$ & $213,832,845$ \\
\hline
\end{tabular}

Lampiran 3 Perhitungan Harga, Titik Impas, Margin Kontribusi dan Laba untuk persamaaan (3)

\begin{tabular}{ccccc}
\hline $\begin{array}{c}\text { Jumlah } \\
\text { Unit yang } \\
\text { diperlukan } \\
\text { untuk } \\
\text { Break Even }\end{array}$ & $\begin{array}{c}\text { Harga } \\
\text { sewa/ } \\
\text { Bulan (Rp) }\end{array}$ & $\begin{array}{c}\text { Margin } \\
\text { Kontribusi } \\
\text { (Rp) }\end{array}$ & $\begin{array}{c}\text { Rasio } \\
\text { Margin } \\
\text { Kontribusi }\end{array}$ & $\begin{array}{c}\text { Laba yang } \\
\text { diperoleh } \\
\text { dengan } \\
\text { Maksimum } \\
96 \text { Unit } \\
\text { tersewa }\end{array}$ \\
\hline 96 & $1,520,228$ & $1,518,421$ & $99.88 \%$ & - \\
95 & $1,536,212$ & $1,534,405$ & $99.88 \%$ & $1,534,405$ \\
94 & $1,552,535$ & $1,550,728$ & $99.88 \%$ & $3,101,456$ \\
93 & $1,569,209$ & $1,567,402$ & $99.88 \%$ & $4,702,207$ \\
92 & $1,586,246$ & $1,584,439$ & $99.89 \%$ & $6,337,758$ \\
91 & $1,603,658$ & $1,601,851$ & $99.89 \%$ & $8,009,255$ \\
90 & $1,621,456$ & $1,619,649$ & $99.89 \%$ & $9,717,895$ \\
89 & $1,639,655$ & $1,637,848$ & $99.89 \%$ & $11,464,933$ \\
88 & $1,658,266$ & $1,656,459$ & $99.89 \%$ & $13,251,676$ \\
87 & $1,677,306$ & $1,675,499$ & $99.89 \%$ & $15,079,493$ \\
86 & $1,696,789$ & $1,694,982$ & $99.89 \%$ & $16,949,818$ \\
85 & $1,716,730$ & $1,714,923$ & $99.89 \%$ & $18,864,150$ \\
84 & $1,737,145$ & $1,735,338$ & $99.90 \%$ & $20,824,062$ \\
83 & $1,758,053$ & $1,756,246$ & $99.90 \%$ & $22,831,200$ \\
82 & $1,779,471$ & $1,777,664$ & $99.90 \%$ & $24,887,293$ \\
81 & $1,801,417$ & $1,799,610$ & $99.90 \%$ & $26,994,154$ \\
80 & $1,823,912$ & $1,822,105$ & $99.90 \%$ & $29,153,686$ \\
79 & $1,846,977$ & $1,845,170$ & $99.90 \%$ & $31,367,891$ \\
78 & $1,870,633$ & $1,868,826$ & $99.90 \%$ & $33,638,869$ \\
77 & $1,894,903$ & $1,893,097$ & $99.90 \%$ & $35,968,834$ \\
76 & $1,919,813$ & $1,918,006$ & $99.91 \%$ & $38,360,114$ \\
75 & $1,945,386$ & $1,943,579$ & $99.91 \%$ & $40,815,161$ \\
74 & $1,971,651$ & $1,969,844$ & $99.91 \%$ & $43,336,561$ \\
73 & $1,998,635$ & $1,996,828$ & $99.91 \%$ & $45,927,040$ \\
& & & &
\end{tabular}




\begin{tabular}{|c|c|c|c|c|}
\hline \multicolumn{5}{|l|}{ Lanjutan } \\
\hline $\begin{array}{c}\text { Jumlah } \\
\text { Unit yang } \\
\text { diperlukan } \\
\text { untuk } \\
\text { Break Even }\end{array}$ & $\begin{array}{c}\text { Harga } \\
\text { sewa/ } \\
\text { Bulan (Rp) }\end{array}$ & $\begin{array}{l}\text { Margin } \\
\text { Kontribusi } \\
\text { (Rp) }\end{array}$ & $\begin{array}{c}\text { Rasio } \\
\text { Margin } \\
\text { Kontribusi }\end{array}$ & $\begin{array}{c}\text { Laba yang } \\
\text { diperoleh } \\
\text { dengan } \\
\text { Maksimum } \\
96 \text { Unit } \\
\text { tersewa }\end{array}$ \\
\hline 72 & $2,026,369$ & $2,024,562$ & $99.91 \%$ & $48,589,477$ \\
\hline 71 & $2,054,883$ & $2,053,077$ & $99.91 \%$ & $51,326,913$ \\
\hline 70 & $2,084,213$ & $2,082,406$ & $99.91 \%$ & $54,142,561$ \\
\hline 69 & $2,114,393$ & $2,112,586$ & $99.91 \%$ & $57,039,821$ \\
\hline 68 & $2,145,460$ & $2,143,653$ & $99.92 \%$ & $60,022,296$ \\
\hline 67 & $2,177,455$ & $2,175,648$ & $99.92 \%$ & $63,093,799$ \\
\hline 66 & $2,210,420$ & $2,208,613$ & $99.92 \%$ & $66,258,378$ \\
\hline 65 & $2,244,398$ & $2,242,591$ & $99.92 \%$ & $69,520,329$ \\
\hline 60 & $2,431,281$ & $2,429,474$ & $99.93 \%$ & $87,461,059$ \\
\hline 40 & $3,646,018$ & $3,644,211$ & $99.95 \%$ & $204,075,805$ \\
\hline 20 & $7,290,229$ & $7,288,422$ & $99.98 \%$ & $553,920,043$ \\
\hline
\end{tabular}

[2] Hanundyasari, DR dan Utomo, C. 2014. Analisis Penetapan Harga Pokok Penjualan Apartemen Puri Park View Tower E Kebon Jeruk - Jakarta Barat. Jurnal Teknik ITS Vol.3 No.2, D147-D152

[3] Septiantoro, UO dan Utomo, C. 2015. Analisis Penetapan Harga Jual Unit Rumah pada Proyek Perumahan Griya Suci Permata Baru, Gresik. Jurnal Teknik ITS Vol.4 No.1, D6-D10.

[4] Puspitowardhani, L. 2005. Penetapan Harga Sewa pada Rumah Susun Sederhana Sewa (Rusunawa) Siwalankerto. TA Program Sarjana S1 Jurusan Teknik Sipil ITS. Surabaya :Tidak dipublikasikan.

Lampiran 4 Perhitungan Harga, Titik Impas, Margin Kontribusi dan Laba untuk persamaaan (4)

\begin{tabular}{|c|c|c|c|c|}
\hline $\begin{array}{c}\text { Jumlah } \\
\text { Unit yang } \\
\text { diperlukan } \\
\text { untuk } \\
\text { Break Even }\end{array}$ & $\begin{array}{c}\text { Harga } \\
\text { sewa/ } \\
\text { Bulan (Rp) }\end{array}$ & $\begin{array}{l}\text { Margin } \\
\text { Kontribusi } \\
\quad(\mathrm{Rp})\end{array}$ & $\begin{array}{c}\text { Rasio } \\
\text { Margin } \\
\text { Kontribusi }\end{array}$ & $\begin{array}{c}\text { Laba yang } \\
\text { diperoleh } \\
\text { dengan } \\
\text { Maksimum } \\
96 \text { Unit } \\
\text { tersewa }\end{array}$ \\
\hline 96 & $1,700,491$ & $1,698,684$ & $99.89 \%$ & - \\
\hline 95 & $1,718,372$ & $1,716,565$ & $99.89 \%$ & $1,716,565$ \\
\hline 94 & $1,736,633$ & $1,734,826$ & $99.90 \%$ & $3,469,652$ \\
\hline 93 & $1,755,287$ & $1,753,480$ & $99.90 \%$ & $5,260,440$ \\
\hline 92 & $1,774,346$ & $1,772,539$ & $99.90 \%$ & $7,090,158$ \\
\hline 91 & $1,793,825$ & $1,792,018$ & $99.90 \%$ & $8,960,090$ \\
\hline 90 & $1,813,736$ & $1,811,929$ & $99.90 \%$ & $10,871,575$ \\
\hline 89 & $1,834,095$ & $1,832,288$ & $99.90 \%$ & $12,826,016$ \\
\hline 88 & $1,854,916$ & $1,853,109$ & $99.90 \%$ & $14,824,876$ \\
\hline 87 & $1,876,217$ & $1,874,410$ & $99.90 \%$ & $16,869,686$ \\
\hline 86 & $1,898,012$ & $1,896,205$ & $99.90 \%$ & $18,962,050$ \\
\hline 85 & $1,920,320$ & $1,918,513$ & $99.91 \%$ & $21,103,647$ \\
\hline 84 & $1,943,160$ & $1,941,353$ & $99.91 \%$ & $23,296,233$ \\
\hline 83 & $1,966,550$ & $1,964,743$ & $99.91 \%$ & $25,541,653$ \\
\hline 82 & $1,990,510$ & $1,988,703$ & $99.91 \%$ & $27,841,840$ \\
\hline 81 & $2,015,062$ & $2,013,255$ & $99.91 \%$ & $30,198,821$ \\
\hline 80 & $2,040,227$ & $2,038,420$ & $99.91 \%$ & $32,614,726$ \\
\hline 79 & $2,066,030$ & $2,064,223$ & $99.91 \%$ & $35,091,794$ \\
\hline 78 & $2,092,495$ & $2,090,688$ & $99.91 \%$ & $37,632,377$ \\
\hline 77 & $2,119,646$ & $2,117,839$ & $99.91 \%$ & $40,238,948$ \\
\hline 76 & $2,147,513$ & $2,145,706$ & $99.92 \%$ & $42,914,114$ \\
\hline 75 & $2,176,122$ & $2,174,315$ & $99.92 \%$ & $45,660,617$ \\
\hline 74 & $2,205,505$ & $2,203,698$ & $99.92 \%$ & $48,481,350$ \\
\hline 73 & $2,235,692$ & $2,233,885$ & $99.92 \%$ & $51,379,364$ \\
\hline 72 & $2,266,719$ & $2,264,912$ & $99.92 \%$ & $54,357,877$ \\
\hline 71 & $2,298,619$ & $2,296,812$ & $99.92 \%$ & $57,420,293$ \\
\hline 70 & $2,331,430$ & $2,329,623$ & $99.92 \%$ & $60,570,206$ \\
\hline 69 & $2,365,193$ & $2,363,386$ & $99.92 \%$ & $63,811,421$ \\
\hline 68 & $2,399,949$ & $2,398,142$ & $99.92 \%$ & $67,147,966$ \\
\hline 67 & $2,435,742$ & $2,433,935$ & $99.93 \%$ & $70,584,110$ \\
\hline 66 & $2,472,620$ & $2,470,813$ & $99.93 \%$ & $74,124,378$ \\
\hline 65 & $2,510,632$ & $2,508,825$ & $99.93 \%$ & $77,773,579$ \\
\hline 60 & $2,719,701$ & $2,717,894$ & $99.93 \%$ & $97,844,179$ \\
\hline 40 & $4,078,648$ & $4,076,841$ & $99.96 \%$ & $228,303,085$ \\
\hline 20 & $8,155,489$ & $8,153,682$ & $99.98 \%$ & $619,679,803$ \\
\hline
\end{tabular}

\section{DAFTAR PUSTAKA}

[1] Hidayat, MF dan Utomo, C. 2014. Analisis Penetapan Harga Jual Unit Rumah di Perumahan Griya Agung Permata, Lamongan. Jurnal Teknik ITS 3 (2), D147-D152. 